\title{
Happiness in active and retired athletes
}

\section{Pocit štěstí u atletů aktivních a těch, kteří již zanechali aktivní dráhu}

\author{
Elżbieta Lewandowska' , Alicja Kostencka' , Inga Dziembowska², Rafał Gotowski' \\ ${ }^{1}$ Casimir the Great University, Bydgoszcz, Poland \\ ${ }^{2}$ Collegium Medicum in Bydgoszcz, Nicolaus Copernicus University in Toruń, Poland
}

\begin{abstract}
Elite athletes lead exceedingly complicated lives. When living under conditions of high demand and allostatic load, happiness may be seriously endangered. Even though many athletes initially feel relief after finishing their athletic career, some of them still suffer depressed mood. The aim of the study was to assess the level of happiness and the differences in happiness profile between active and retired elite athletes. Also, the sport discipline and social support were taken into consideration as factors influencing athletes' happiness - a construct that reflects people's subjective and global evaluations of their lives. 110 active and retired elite athletes from Poland filled in three psychological questionnaires, which reflect subjective happiness: the Flourishing Scale (FS) to assess core aspects of social-psychological functioning, The Emotional Wellness Scale (EWS) to assess the affective component of happiness and Satisfaction With Life Scale (SWLS) to assess the judgmental component of subjective well-being. No significant differences were found neither between active and retired athletes, nor between individual and team sport. However, we found significant influence of social support on both retired and active athletes' happiness. These findings have implications for how well athletes cope with stress which, in turn, could shed light on the development of factors that may provide a buffer against adversity and build resilience.
\end{abstract}

\begin{abstract}
Abstrakt
Elitní atleti vedou mimořádně komplikované životy. Život pod tlakem náročných požadavků a alostatické zátěže může vážně ohrožovat pocit štěstí. Přestože mnozí sportovci zpočátku po skončení atletické kariéry cítí úlevu, někteří z nich trpí depresivní náladou. Cílem studie bylo zhodnotit úroveň štěstí a rozdíly $v$ profilu štěstí mezi aktivními a bývalými elitními sportovci. $V$ úvahu jako faktory ovlivňující štěstí sportovců byly vzaty sportovní disciplína a sociální podpora - konstrukt, který odráží lidské subjektivní a globální hodnocení svého života. 110 aktivních a již neaktivních elitních sportovců z Polska vyplnilo tři psychologické dotazníky, které odrážejí subjektivní štěstí: Flourishing Scale (FS) k posouzení základních aspektů sociálně-psychologického fungování, Emotional Wellness Scale (EWS) k posouzení afektivní složky štěstí a Satisfaction With Life Scale (SWLS) k posouzení rozhodovací složky subjektivního blahobytu. Nebyly zjištěny žádné významné rozdily mezi aktivními a již neaktivními sportovci ani mezi individuálním a týmovým sportem. Zjistili jsme ovšem významný vliv sociální podpory na štěstí po skončení aktivní kariéry i u aktivních sportovců. Tato zjištění mají dopad na to, jak dobře se sportovci vyrovnávají se stresem, což mủže osvětlit vývoj faktorů, které mírní nepřizeň a pomáhají vybudovat odolnost.
\end{abstract}

Keywords: Well-being, sport, social support

Klíčová slova: Well-being, sport, sociální podpora 


\section{INTRODUCTION}

Practicing sports is often seen by the players as an appointment of life. Striving for victory, success and excellence is associated with the development of talent, self-realization, which can provide the player with a sense of accomplishment.

The discovery of one's passion for life, a total commitment in the work providing satisfaction and a sense of competence allows to experience well-being, including the so-called flowstate experiencing flow, which - if experienced on regular basis - is a determinant of happiness (Csíkszentmihályi, 1999).

The level of happiness may vary depending on various factors. They are largely determined by intentional activity associated with the ability to impact one's life in a way that it provides high degree of satisfaction with fulfilling the goals (Jasielska \& Jarymowicz, 2012). By working on yourself, one can provide life with value and meaning and enrich them with additional sources of positive emotions, which in turn increases the level of their own happiness (Sheldon \& Lyubomirsky, 2006). Participation in sports thus appears to be the ideal way to achieve a high level of happiness or welfare ${ }^{1}$.

Analyzing the psychological aspects we must, however, pay attention to positive and negative emotions associated with the practice of competitive sports. The positives may include satisfaction with the performance, contentment, pleasure, but athletes also often experience negative feelings, such as stress of competition or pressure on the result, fear (most often of failure), and sadness. Certainly, satisfaction with the appearance of athletic body and overall physical fitness is an important part of subjective feeling of well-being. Well-being may also be significantly influenced by interpersonal relationships. In sport groups, positive relationship is most commonly observed. This is very important because the appropriate system of relations in a team allows to achieve a common goal and it has an impact on individual or team satisfaction (Gracz \& Sankowski, 2007). Of course, athletes achieve satisfaction and happiness, not only in sport, and thanks to it, but also in everyday life. Recognition of the various factors that have an impact on the welfare of the athletes is a very interesting research task, which is why we have chosen such a subject of research.

An important aspect of sport is not only the pursuit of the sports score, but also developing one's own happiness, satisfaction, experiencing pleasure despite the hard work and fulfilment of the needs of joy for others (Chelladurai, 2007). Research shows that success of athletes is the result of long-term mental and physical commitment during training and competition. The best of them, not only try to reach the top, but also to stay on it as long as possible (Wylleman \& Lavallee, 2004).

These athletes lead very complicated lives. In conditions of high emotional tension and pressure, their happiness may be seriously jeopardized. For most of them practising sport despite the stress also brings great satisfaction. Inevitably, however, there comes the moment when an athlete finishes his sporting career.

A career transition is "an event or nonevent (which) results in a change in assumptions about oneself and the world and thus requires a corresponding change in one's behavior and relationships" (Schlossberg, 1981, p. 5). Athletic retirement is defined as "the clearest example of a nor-

\footnotetext{
${ }^{1}$ Happiness is often equated with momentary sensations, whereas the term well-being (welfare), according to Seligmann (2011) better reflects the long-term, overall life satisfaction, because the welfare of a man consists of such elements as experiencing positive emotions, engagement in the implementation of objectives, the quality of interpersonal relationships, a sense of meaning (having a goal in life and need to implement values) and the need for achievements (Seligmann, 2011). For this study, we adopted the use of these two terms interchangeably basing on the approach of Diener \& Biswas-Diener (2010, p. 18) defining happiness as "subjective sense of well-being."
} 
mative and even inevitable transition" (Alfermann, \& Stambulova, 2007). Retirement is almost a taboo subject in sport, which is remarkable given that it happens to every athlete. The reasons for career termination seem to play a crucial role for adjustment to post-career life (Alfermann, Stambulova, \& Žemaitytè, 2004). It may also contribute to differences in the quality of life. Although many athletes initially feel relieved afterwards, some of them feel negative emotions and have difficulty accepting the new situation that they encounter.

International studies show that the end of their sporting career and the transition to retirement is a multifactorial, multi-dimensional and multi-level process, in which a key role is played by nationality and culture (Alfermann, Stambulova, \& Žemaitytė, 2004; Stambulova, Stephan, \& Jäphag, 2007).

This process also depends on whether the career was terminated voluntarily, on the subjective assessment of the athletess own performance is sports, and even on his or her level of education (CecićErpič, Wylleman \& Zupančič, 2004). Education proves to be very important for the athlete, because it allows for faster adaptation and a smooth transition from one type of career to another (e.g. from sports to work) (Borggrefe \& Cachay, 2012; Corrado et al., 2012). The need to prepare for the end of a career is therefore observed even while participating in elite sports (Aquilina, 2013; Park, Tod, \& Lavallee, 2012). When practising sport on a professional level, an athlete must be aware that this is one of the shortest careers that one can have. Most professional athletes retire at a young age, which forces them to redefine their sense of life and social identity (Witnauer, Rogers $\&$ Saintonge, 2007). Welfare and quality of life of the athletes after retirement depends both on sports factors (e.g. success, sports identity) and unsportsmanlike factors (e.g. the course of work or study, family support, and retirement planning) (CecićErpič, Wylleman \& Zupančič, 2004; Stambulova, Stephan \& Jäphag, 2007). Research by Wolff, et al. (2013) confirm that if support is appropriately tailored to the needs of a person, it is closely related to the well-being and stress reduction. He also stresses the importance of planning the end of sporting career as a process, not a sudden departure, as if by accident (Torregrosa et al., 2004).

Factors affecting the current level of life satisfaction in athletes after going on sports retirement was vividly presented in the research by Kadlcik \& Flemr, (2008).

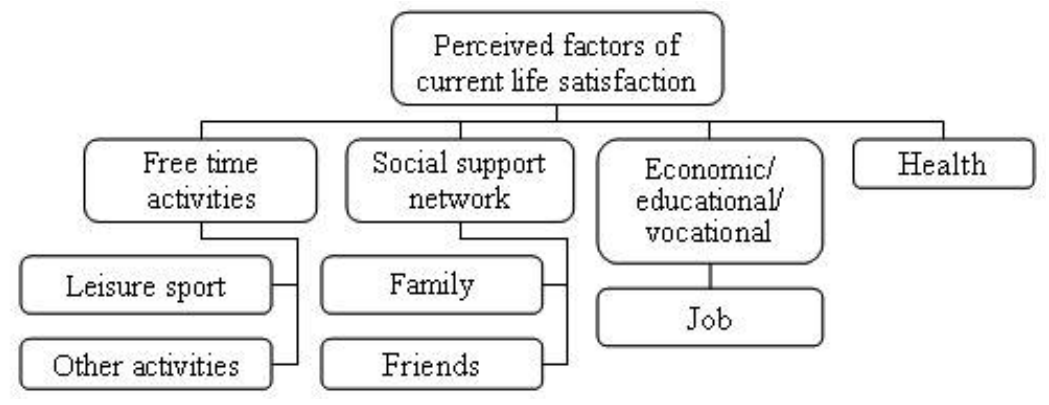

Fig. 1: Perceived factors of participants' (eleven former elite athletes) current life satisfaction (Kadlcik \& Flemr, 2008).

The researchers established this model basing on the data acquired in interviews with the participants. Participants were asked to name the factors related to their current life satisfaction. Data units forming this category are divided into four high order themes (presented in Figure 1): free time activities, family/social network, vocational area and health issue was mentioned as a source of life satisfaction. In these studies, the players stressed in particular the importance of active leisure time activities for their satisfaction with life, having a happy family and satisfaction with work (Kadlcik \& Flemr, 2008). 
Due to the many different sources of happiness in active and retired professional athletes, we decided to consider only some of them in our study.

\section{AIM OF THE STUDY}

Considering the tremendous political and economic changes in Poland, it seemed especially attractive to compare the level of happiness of active and retired elite athletes. The aim of the study was to assess the level of happiness and the differences in happiness profile between active and retired elite athletes. As social relationships have been shown to be of additional importance for coping, the second aim of this study is to examine whether there are factors contributing to higher levels of happiness such as social support of type of athletic performance (individual of team sports). With the results of this study it could be possible to highlight contributing/reducing factors related to retirement. This study contributes to researchers being able to produce new effective strategies and tools to help athletes cope with the athletic retirement process.

\section{METHODS}

Research on the profile of happiness and the level of social relations in athletes, was conducted in 54 active ( 30 females and 24 males) and 56 retired ( 29 females and 27 males) Polish athletes, who practised such sports as volleyball, handball, football, basketball, athletics, swimming, rowing, canoeing, martial arts, tennis, fencing, dance.

The respondents, who train competitive sports, achieved successes in Polish Championships (the highest percentage of respondents), World Championships or the Olympic Games, European Championships or the International Championships of Poland or the Polish First Division.

All participants were briefed of the study protocol using an information sheet, and their informed written consent for participating in the study was obtained.

- The participants - active and retired elite athletes from Poland completed the questionnaire suggested by Diener and Bieswas-Diener (2008) on the strengths and weaknesses in the area of interpersonal relationships. The questionnaire consisted of 10 items. The scale had good psychometric properties in the current study (Cronbach $\alpha=0.75$ )

- Apart from this, the participants completed also three psychological questionnaires, which reflect subjective happiness:

- The Polish adaptation of Flourishing Scale (FS) - Skala Rozkwitu Psychicznego which is an 12-item-scale measuring a core aspect of optimal social-psychological functioning on a 7-point Likert scale ranging from 1 (strongly disagree) to 7 (strongly agree) to assess core aspects of socio-psychological functioning (Diener, et al., 2009; Juczyński, 2001). The scale had good psychometric properties in the current study (Cronbach $\alpha=0.92$ )

- The Polish adaptation of Emotional Wellness Scale (EWS) - Skala Dobrostanu Emocjonalnego which consists to assess the affective component of happiness (Diener \& Biswas-Diener, 2008, Juczyński, 2001). The scale consists of 16 adjectives naming positive (8) and negative (8) feelings. Perticipants reported how much they had experienced each of the feelings, using 5-point Likert scale ranging from 1 (very rarely or never) to 5 (very often or always). The questionnaire had good psychometric properties in the current study (Cronbach $\alpha=0.84$ )

- The Polish adaptation Satisfaction with Life Scale (SWLS) - Pomiar Satysfakcji Życiowej, which is a short 5-item measure to assess the judgmental component of subjective well-being (Diener et al., 1985, Juczyński, 2001). The scale had good psychometric properties in the current study (Cronbach $\alpha=0.78$ ) 
According to Diener \& Biswas-Diener R., (2008), the sum of these measurements allows to assess the profile of the person's happiness using a key specified in the table below (tab. 1).

Tab. 1: Profile of happiness

\begin{tabular}{|l|c|c|c|c|c|c|c|}
\hline $\begin{array}{l}\text { Elements } \\
\text { of psychological } \\
\text { wealth }\end{array}$ & $\begin{array}{c}\text { Extremely } \\
\text { low }\end{array}$ & $\begin{array}{c}\text { Very } \\
\text { low }\end{array}$ & Low & Average & High & $\begin{array}{c}\text { Very } \\
\text { high }\end{array}$ & $\begin{array}{c}\text { Extremely } \\
\text { high }\end{array}$ \\
\hline Life satisfaction & $(5-9)$ & $(10-14)$ & $(15-19)$ & $(20)$ & $(21-25)$ & $(26-30)$ & $(31-35)$ \\
\hline Positive feelings & $(8-13)$ & $(14-18)$ & $(19-23)$ & $(24-27)$ & $(28-30)$ & $(31-35)$ & $(36-40)$ \\
\hline $\begin{array}{l}\text { Low level of } \\
\text { negative feelings }\end{array}$ & $(32-40)$ & $(29-32)$ & $(26-28)$ & $(21-25)$ & $(17-20)$ & $(12-16)$ & $(8-11)$ \\
\hline $\begin{array}{l}\text { Psychological } \\
\text { flourish }\end{array}$ & $(12-31)$ & $(32-47)$ & $(48-59)$ & $(60-67)$ & $(68-73)$ & $(74-79)$ & $(80-84)$ \\
\hline
\end{tabular}

Source: Diener, Biswas-Diener, 2010, p. 254

Statistical analysis was performed using Statistica 12.5 (Statsoft, Poland). The relationships between the study variables were presented using multi-way tables. Verification of the relationships between elements of psychological wealth and gender, sport performance (active/retired) and type of sport discipline (individual/team) was performed using Pearson's chi-square test of independence. If the assumptions of the minimum expected size $(<5)$ are not made, Yates adjustment was applied for continuity test for the chi-square test, taking into account the degrees of freedom (Df) as a derivative amount of variants of answers to the questions included in tables.

\section{RESULTS}

\section{Profile (level) of athletes' happiness}

The research assumes that there might be differences in the profile of happiness athletes in depending on the nature of the sport discipline. No differences have been found between males and females in analysed elements of psychological wealth in the whole group within groups of retired and active athletes (all $\mathrm{p}>0.10$ ).

The following analysis refers to the level and differences in the level (profile) of happiness among athletes training team and individual disciplines (Table 2). 
Tab. 2: Level (profile) of happiness depending on the types of sports

\begin{tabular}{|l|c|c|c|c|c|c|}
\hline \multirow{2}{*}{$\begin{array}{l}\text { Level } \\
\text { of Hype of sport }\end{array}$} & \multicolumn{2}{|c|}{ Individual } & \multicolumn{2}{c|}{ Team } & \multicolumn{2}{c|}{ Total } \\
\cline { 2 - 7 } & $\mathbf{N}$ & \% & N & $\%$ & N & $\%$ \\
\hline $\begin{array}{l}\text { Extremely high level } \\
\text { of happiness }\end{array}$ & 1 & 1.5 & 0 & 0 & 1 & 0.9 \\
\hline $\begin{array}{l}\text { Extremely high level } \\
\text { of happiness }\end{array}$ & 11 & 16.9 & 8 & 17.8 & 19 & 17.3 \\
\hline High level of happiness & 39 & 60 & 21 & 46.7 & 60 & 54.5 \\
\hline Average level of happiness & 9 & 13.9 & 12 & 26.7 & 21 & 19.1 \\
\hline Low level of happiness & 4 & 6.2 & 3 & 6.7 & 7 & 6.4 \\
\hline Very low level of happiness & 1 & 1.5 & 1 & 2.2 & 2 & 1.8 \\
\hline $\begin{array}{l}\text { Extremely low level of } \\
\text { happiness }\end{array}$ & 0 & 0 & 0 & 0 & 0 & 0 \\
\hline Total & 65 & 100 & 45 & 100 & 110 & 100 \\
\hline
\end{tabular}

$$
\mathrm{Chi}^{2}=2,64 \quad \mathrm{df}=5 \quad \mathrm{p}>0,05 \quad(\mathrm{p}=0,765)
$$

The largest group of people showed a high level of happiness, which was observed in $60.0 \%$ of athletes practicing individual type of sports and $46.7 \%$ athletes practicing team types of sport.

In addition, average level of happiness was observed in more than a quarter of athletes training team games $(26.7 \%)$ and only $13.8 \%$ of athletes training individual types of sport.

The third most frequently observed performance profile of happiness is very high level observed in $16.9 \%$ of representatives of the individual type of sports and $17.8 \%$ of athletes training team games. Low levels of happiness apply to $6.7 \%$ of the surveyed players of team sports and $6.2 \%$ of individual athletes.

At the significance level of 0.05 , no statistically significant $(p=0.765)$ relationship between the level profile of happiness and a type of sport was observed.

The percentages of competitors practising individual and team sports in terms of the profile of happiness are not significantly different.

The differences in the happiness level (profile) between training athletes and athletes who completed their sporting career were also examined. The results are presented in Table 3.

Tab. 3: Level (profile) of happiness depending on the sports classification of athletes

\begin{tabular}{|l|c|c|c|r|c|c|}
\hline \multirow{2}{*}{$\begin{array}{l}\text { Level } \\
\text { of Happiness }\end{array}$} & \multicolumn{2}{|c|}{ Training athlete } & \multicolumn{2}{c|}{ Retired athlete } & \multicolumn{2}{c|}{ Total } \\
\cline { 2 - 7 } & $\mathbf{N}$ & $\mathbf{1}$ & $\mathbf{N}$ & \multicolumn{1}{c|}{$\%$} & $\mathbf{N}$ & $\%$ \\
\hline $\begin{array}{l}\text { Extremely high level } \\
\text { of happiness }\end{array}$ & 1 & 1.9 & 0 & 0 & 1 & 0.9 \\
\hline $\begin{array}{l}\text { Extremely high level } \\
\text { of happiness }\end{array}$ & 10 & 18.9 & 9 & 15.8 & 19 & 17.3 \\
\hline High level of happiness & 28 & 52.8 & 32 & 56.1 & 60 & 54.5 \\
\hline Average level of happiness & 12 & 22.6 & 9 & 15.8 & 21 & 19.1 \\
\hline Low level of happiness & 2 & 3.8 & 5 & 8.8 & 7 & 6.4 \\
\hline Very low level of happiness & 0 & 0 & 2 & 3.5 & 2 & 1.8 \\
\hline $\begin{array}{l}\text { Extremely low level } \\
\text { of happiness }\end{array}$ & 0 & 0 & 0 & 0 & 0 & 0 \\
\hline Total & 53 & 100 & 57 & 100 & 110 & 100 \\
\hline
\end{tabular}

$\mathrm{Chi}^{2}=1,27 \quad \mathrm{df}=5 \quad \mathrm{p}>0,05 \quad(\mathrm{p}=0,938)$


As shown in the table above, athletes of both classifications achieve a high level of happiness ( $56.1 \%$ of retired athletes, $52.8 \%$ of training athletes). Not a very high percentage $-8.8 \%$ of the athletes who finished their career shows a low level of happiness, and a very low level is observed in $3.5 \%$ of them. Even lower percentage applies to athletes that are currently trainees (respectively $3.8 \%$ and $0 \%$ ). Whereas a higher percentage of active athletes than the athletes at the end of their sporting career is characterized by a very high (18.9\% and $15.8 \%)$ or extremely high $(1.9 \%$ and $0 \%$ ) level of happiness. However, no statistically significant differences in the level (profile) of happiness between active athletes and athletes who completed their sporting career.

\section{Connections between social relations and the level (profile) of happiness in athletes}

The last analysis concerns the relationships between the profile of happiness and social relations in the surveyed athletes. These relationships have been presented by determining the statistical significance of differences between the group of athletes with normal and low level of interpersonal relationships. This is presented in Table 4.

Tab. 4: Connections of social relations with the happiness profile

\begin{tabular}{|c|c|c|c|c|c|c|}
\hline \multirow{3}{*}{$\begin{array}{l}\text { Level } \\
\text { of happiness }\end{array}$} & \multicolumn{6}{|c|}{ Level of social relations } \\
\hline & \multicolumn{2}{|c|}{ Low } & \multicolumn{2}{|c|}{ Normal } & \multicolumn{2}{|c|}{ Total } \\
\hline & $\mathbf{N}$ & $\%$ & $\mathbf{N}$ & $\%$ & $\mathbf{N}$ & $\%$ \\
\hline $\begin{array}{l}\text { Extremely high level of } \\
\text { happiness }\end{array}$ & 0 & 0 & 1 & 1.1 & 1 & 0.9 \\
\hline $\begin{array}{l}\text { Extremely high level of } \\
\text { happiness }\end{array}$ & 0 & 0 & 19 & 21.1 & 19 & 17.3 \\
\hline High level of happiness & 4 & 20 & 56 & 62.2 & 60 & 54.5 \\
\hline Average level of happiness & 8 & 40 & 13 & 14.4 & 21 & 19.1 \\
\hline Low level of happiness & 6 & 30 & 1 & 1.1 & 7 & 6.4 \\
\hline Very low level of happiness & 2 & 10 & 0 & 0 & 2 & 1.8 \\
\hline $\begin{array}{l}\text { Extremely low level of } \\
\text { happiness }\end{array}$ & 0 & 0 & 0 & 0 & 0 & 0 \\
\hline Total & 20 & 100 & 90 & 100 & 110 & 100 \\
\hline
\end{tabular}

$$
\mathrm{Chi}^{2}=34,21 \quad \mathrm{df}=5 \quad \mathrm{p}<0,001 \quad(\mathrm{p}=0,000 * * *)
$$

At the significance level of $p<0.0001$ statistically significant differences were observed in the level of happiness profile among athletes whose social relationships are correct, and those whose relations are at a low level. People with a normal level of social relationships show a high level of happiness more often $(62.2 \%)$ than people with low levels of social relationships $(20.0 \%)$. On the other hand, people with a low level of social relationships often show the average level of happiness $(40.0 \%)$ compared to only $14.4 \%$ of people with the same profile in the group with normal levels of social relations.

In addition, nearly one-third of people with low levels of social relationships (30.0\%) showed a low level of happiness as compared to $1.1 \%$ in those with a normal level of relationships.

Apart from the above dependencies, nearly every fifth $(21.1 \%)$ of the polled with a correct level of social relations demonstrated a very high level of happiness, compared to the percentage of $0.0 \%$ in those with a low level of social relations. 


\section{DISCUSSION}

Research on happiness profile is rarely conducted in groups of athletes training professionally, but in literature we can find a lot of studies by Polish authors on the relationship of physical activity and the level of happiness or quality of life (Grześkowiak \& Siwa-Hudowska, 2016, Majewska, 2011; Smith, 2012; Ruseski, 2014).

In studies by Debris \& Jedrek, (2010) an attempt was made to assess the relationship between the quality of life in athletes training professionally in individual and team type of sport and their type of sports activity. It was noted that the quality of life in athletes of team or individual sports is at a high level, but athletes of team types of sport get lower indicators of quality of life. The researchers also found that the predicted evaluation of the quality of life in 5 years will significantly increase in people practising team type of sports. However, own research shows that both the athletes of individual and team type of sports achieve a high level of happiness and there are no statistically significant differences between the two groups.

It is well known that sport has a huge impact on the mental and physical feeling of contentment, satisfaction and well-being of a man. However, in our study there was a higher level of happiness athletes who are currently trainees than in those who have completed their sporting career. However focusing on sport retirement as an event that occurs in isolation is likely to mislead research efforts. This is a concern and many factors such as gender, race, socioeconomic status and the existence of support systems may influence the adjustment process. In our study, however, gender did not affect significantly the level of happiness. As both active and retired elite athletes in Poland achieve greater occupational status and even higher incomes, their socioeconomic status did not differ in the presented study.

Perhaps, this is due to the high level of recreational physical activity in former athletes or finding another passion, which affected their level of happiness. Our results show, however, that there is a very important relationship between the level of social relations and the achieved level of happiness. Thus, subjective well-being after the change of status of the athlete from active to retired can be mainly dependent on those around the athlete to help him in the process of transformation and fill the "gap" arising after the completion of the sports career. An athlete ending his or her sports career needs internal transformation, which is usually based on relationships with others.

Redefining themselves well before the end of their sports careers can protect athletes from losing the meaning of life during the process of transformation of their identity (Lally, 2007). Stress resulting from the completion of their sports careers is soothed by athletes' contacts with parents and with the people that are part of their careers, e.g. coaches, managers (Fogarty \& Albion, 2014), who can support them on this way. Therefore, in the process of going retired in sports it is important that people surrounding the athletes cooperate to support them in creating a new identity, developing their strengths, discovering non-sport talents, providing support on various levels of functioning. Such a "prevention" at an early stage of retiring process can significantly improve the well-being of the athlete (Park, Tod \& Lavallee, 2012), which in turn may also affect his or her happiness.

This could confirm the importance of social relationships for retired athletes, as observed in our study in relation to subjective well-being. Our research shows that the vast majority of active and retired athletes show high levels of happiness. Certainly, the ability to cope with stress, developed over the years of training and competing in competitions, is of high importance in this regard.

The ability to positively cope with stress and changes when practising sports and after the sporting career, ensures successful and long life for the athletes, whether they are active or retired, while the lack of such skills often results in negative consequences (e.g. premature termination of the sports career, neurosis, addiction to alcohol or drugs, etc.). That is why athletes need 
help to prepare for and cope with transition situations in their career, which should be the basis of concern for coaches, managers, parents, and sports psychologists (Stambulova, Alfermann, \& Statler, 2009).

However, retirement should not be a source of stress, identity crises or other problems, as the dynamics of retirement in sport is placed in a social context in which retirement takes place. Factors such as gender, race, age, socio-economic status, social and emotional support shape the way in which the player ends his career. The end of sports career could potentially be the cause of stress and trauma, but it is usually not the main cause of these problems (Coakley, 1983). Psychophysical changes, e.g. a change in the appearance of silhouette may also contribute (Stephan, Torregrosa \& Sanchez, 2007). As early as several years ago, the results of the research by Grove et al. (1997) showed that adoption of positive reinterpretation, planning and active coping with stress, were the most frequently used coping strategies in the personal, professional, financial and emotional transformation process and in social adjustment to sport retirement in the athletes.

The process of ending a career and adapting to the sport retirement in the Czech Republic was studied by Kadlcik and Flemr (2008). The results of these studies were confirmed in the multi-faceted reasons for termination of career. Most often, the polled athletes voluntarily ended their career, due to the decline in motivation to train, which did not cause negative consequences of retiring in other areas of life. Therefore, it can be assumed that, as observed in our study, the level of satisfaction with life pin athletes after the completion of their sporting career was not lower than in active athletes.

According to Lundqvist and Sandin (2014), who carried out a qualitative study in retired players, close, solid relationships, good interpersonal communication allows the discovery of potential needs for support and improves the physical condition of athletes. On the contrary, problems and disturbances in relationships with relatives, friends and coaches adversely affect their psychology. They significantly reduce the level of welfare and usually negatively affect performance in sport (Lundqvist \& Sandin, 2014).

Many athletes have close friends, both related and unrelated to sport, who are a source of stable and constantly available support. Sport allows to meet new people, develop friendships that this will translate into new and close relations also in private life.

This confirms the importance of social relationships for both active and retired athletes.

Belonging to a sports group brings not only positive experiences of sport, but especially for young people, it allows them to develop personal and social skills (MacDonald, et al., 2011), which often thrive on affection and trust to their parents and allow to create other, safe, and close relationships (Carr \& Fitzpatrick, 2011).

The research results therefore confirm that social relationships of athletes have a significant impact on the level of happiness.

Currently, there are not enough up-to-date analyzes and comparisons measuring the level of happiness or well-being of active and retired athletes.

Studies of happiness in professional athletes are difficult because of conceptual ambiguity. There are various models used, usually of hedonistic approach, making it difficult to compare results across studies (Lundqvist, 2011).

Therefore, extreme caution is recommended in generalizing the results until the different populations of professional athletes will be tested with the same tools and in similar conditions so that the interpretations and comparisons could be credible. 


\section{CONCLUSIONS}

Sport is a factor that significantly affects the level of happiness in athletes. Polish athletes reach high or very high level of happiness regardless of whether they are currently training or they actively practised sport in the past.

The studies showed that there was no statistically significant difference between the levels of happiness in retired athletes and in active athletes. No differences were also found between the level of happiness and the type of sport. There was, however, a statistically significant effect of social relationships on the level of happiness, in both retired and active athletes.

These findings may be important for athletes, also regarding the ability to cope with stress, which in turn could influence the development of the factors that could constitute a buffer that can help to overcome obstacles and build a psychological resistance. Retired athletes are then in need of intervention programmes, especially those focusing of social support.

\section{References}

Aquilina, D. (2013). A Study of the Relationship Between Elite Athletes'Educational Development and Sporting Performance. The International Journal of the History of Sport, 30(4): 374-392.

Alfermann, D., Stambulova, N., \& Žemaitytè, A. (2004). Reactions to sport career termination: a cross-national comparison of German, Lithuanian, and Russian athletes. Psychology of Sport and Exercise, 5(1): 61-75.

Borggrefe, C. \& Cachay, K. (2012). "Dual Careers": The Structural Coupling of Elite Sport and School Exemplified by the German Verbundsysteme. EJSS. European Journal for Sport and Society, 9(1/2): 57-80.

Carr, S. \& Fitzpatrick, N. (2011). Experiences of dyadic sport friendships as a function of self and partner attachment characteristics. Psychology of Sport \& Exercise Psychology, 12: 383-391.

CecićErpič S, Wylleman P, Zupančič M. (2004). The Effect of Athletic and Non-Athletic Factors on the Sports Career Termination Process. Psychology of Sport and Exercise, 5(1): 45-59.

Chelladurai, P. (2007). Leadership in sports [in:] Handbook of sport psychology (ed.) Tanenbaum G., Eklund L. K., John Wiley \& Sons, Inc: 113-135.

Coakley, J. J. (1983). Leaving Competitive Sport: Retirement or Rebirth? Quest, 35 (1): 1-11.

Csikszentmihalyi, M. (1999). If we are so rich, why aren't we happy? American Psychologist, 54: 821-827.

Derbis, R., Jedrek, K. (2010) Poczucie jakości życia a osobowość sportowców dyscyplin indywidualnych i zespołowych [The sense of quality of life and personality of athletes in individual and team disciplines], Psychological Review, 53 (1): 9-32.

Diener E., Biswas-Diener R. (2010) Szczęście. Odkrywanie bogactwa psychicznego [Happiness. Discovering the Psychological Wealth], Smak Słowa, Sopot.

Diener, E., Emmons, R. A., Larsen, R. J., \& Griffin, S. (1985). The Satisfaction with Life Scale. Journal of Personality Assessment, 49: 71-75.

Diener, E., Wirtz, D., Tov, W., Kim-Prieto, C., Choi, D., Oishi, S., \& Biswas-Diener, R. (2009). New measures of well-being: Flourishing and positive and negative feelings. Social Indicators Research, 3: 247-266.

Gracz, J. \& Sankowski, T. (2007). Psychologia aktywności sportowej [Psychology of Sport Activity], The Publishing House of Physical Education Academy, p 468.

Grove, J.R., Lavallee, D. \& Gordon, S. (1997). Coping with retirement from sport: The influence of athletic identity. Journal of Applied Sport Psychology, 9 (2): 129-147.

Grześkowiak, B. \& Siwa-Hudowska, A. (2016) Temperament, poczucie własnej skuteczności i jakość życia kobiet regularnie uprawiających sport w porównaniu z kobietami nieaktywnymi fizycznie [Temper, a sense of self-efficacy and quality of life of women practicing sport regularly, compared with physically inactive women.]. Journal of Education, Health and Sport, 6(6): 359-374.

Jasielska, D. \& Jarymowicz, M. (2012). Significance given to positive emotions about automatic and reflexive genesis and indicators of happiness level. Roczniki Psychologiczne [Psychological Yearbooks], 2(15): 7-30.

Juczyński Z. (2001). Narzędzia pomiaru w promocji i psychologii zdrowia. Pracownia Testów Psychologicznych Polskiego Towarzystwa Psychologicznego, Warszawa, 123-127.

Kadlcik, J. \& Flemr, L. (2008). Athletic Career Termination Model in the Czech Republic. A Qualitative Exploration. International Review for the Sociology of Sport, 43(3): 251-269.

Lally P. (2007). Identity and Athletic Retirement: A Prospective Study. Psychology of Sport and Exercise. 8(1): 85-99.

Lundqvist, C. Well-being in competitive sports - the feel-good factor? A review of conceptual consideration of well-being. International Review of Sport and Exercise Psychology, 2011, 4; 109-127.

Lundqvist, C., Sandin, F. (2014). Well-being in elite sport: Dimensions of hedonic and eudaimonic well-being among elite orienteers. The Sport psychologist, 28(3): 245-254. 
MacDonald, DJ, Côté, J., Eyes, M. \& Deakin, J. (2011). The role of enjoyment and motivational climate in relation to the personal development of team sport athletes. The Sport Psychologist, 25: 32-46.

Majewska, K. (2011). Tenisowa aktywność rekreacyjna a poczucie szczęścia mieszkańców Wielkopolski [Tennis recreational activity and a feeling of happiness in the inhabitants of the Greater Poland] [in] Sport i rekreacja a wyzwania współczesnej cywilizacji [Sport and recreation and the challenges of modern civilization], Publishing House of the University of Szczecin, Szczecin: 197-214.

Martin, L. A., Fogarty, G. \& M. Albion (2014). Changes in Athletic Identity and Life Satisfaction of Elite Athletes as a Function of Retirement Status. Journal of Applied Sport Psychology. 26(1): 96-110.

Nowak, P.F. (2012) Związki deklarowanej aktywności i sprawności fizycznej z samooceną dobrostanu psychicznego u maturzystów [Relationship of declared activity and physical fitness with self-assessment of mental well-being in high school graduates.]. Medycyna Ogólna i Nauki o Zdrowiu [General Medicine and Health Sciences], 18(4): 361-365.

Park, S., Tod, D. \& Lavallee, D. (2012). Exploring the Retirement from Sport Decision-Making Process Based on the Transtheoretical Model. Psychology of Sport and Exercise, 13(4): 444-53.

Ruseski, J.E., Humphreys, B.R., Hallman, K., Wicker, P., Breuer, C. (2014) Sport Participation and Subjective Well-Being: Instrumental Variable Results From German Survey Data, Journal of Physical Activity and Health, 11: 396-403.

Schlossberg, N. K. (1981). A model for analyzing human adaption to transition. The Counseling Psychologist, 9(2), 2-18.

Seligmann, M. E. P. (2011). Flourish. New York: Free Press.

Sheldon, K. M. \& Lyubomirsky, S. (2006). Achieving sustainable gains in happiness: Change your actions, not your circumstances. Journal of Happiness Studies, 7(1): 55-86.

Stambulova, N., Alfermann, D. \& Statler, T. (2009). ISSP Position stand: Career development and transitions of athletes. International Journal of Sport and Exercise Psychology, 7(4): 395-412.

Stambulova, N., Stephan, Y., \& Jäphag, U. (2007). Athletic retirement: A cross-national comparison of elite French and Swedish athletes. Psychology of Sport and Exercise, 8(1): 101-118.

Stephan, Y., Torregrosa, M. \& Sanchez X. (2007). The body matters: Psychophysical impact of retiring from elite sport. Psychology of Sport and Exercise, 8(1): 73-83.

Torregrosa M, Boixadós M, L Valiente, Cruz, J. (2004). Elite Athletes' Image of Retirement: The Way to Relocation in Sport. Psychology of Sport and Exercise, 5(1): 35-43.

Witnauer, W. D., Rogers, R. G., \& Saint Onge, J. M. (2007). Major league baseball career length in the 20th century. Population Research and Policy Review, 26(4): 371-386.

Wolff, J. K., Schmiedek, F., Brose, A., \& Lindenberger, U. (2013). Physical and emotional wellbeing and the balance of needed and received emotional support: Age differences in a daily diary study. Social Science \& Medicine, 91: 67-75.

Wylleman, P., Alfermann, D., \& Lavallee, D. (2004). Career transitions in sport. Psychology of Sport and Exercise, 5 (1): 3-5. 